\title{
EFEKTIVITAS E-MODUL LARUTAN ELEKTROLIT DAN NONELEKTROLIT BERBASIS GUIDED DISCOVERY LEARNING TERHADAP HASIL BELAJAR SISWA KELAS X Yerimadesi*, Azizah Kristalia ${ }^{2}$
}

1,2 Prodi Pendidikan Kimia, Universitas Negeri Padang

*Corresponding Author: yeri@fmipa.unp.ac.id

\section{ART ICLE INFO}

Article history:

Received July 30, 2021

Revised August 09, 2021

Accepted September 12, 2021

Available online October 25, 2021

Kata Kunci:

Efektivitas, Guided

Discovery Learning

Elektrolit dan Nonelektrolit

Hasil Belajar

Keywords:

Effectiveness, Guided

Discovery Learning,

Electrolyte and

Nonelectrolyte, Learning

Outcomes

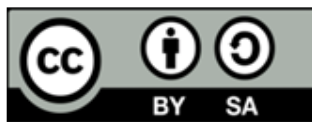

\begin{abstract}
A B S T R A K
Materi larutan elektrolit dan nonelektrolit merupakan salah satu materi kimia yang bersifat abstrak dan sulit dipahami oleh siswa. Tujuan dari penelitian ini untuk menganalisis efektivitas e-modul larutan elektrolit dan nonelektrolit berbasis guided discovery learning terhadap hasil belajar peserta didik. Jenis penelitian yang digunakan eksperimen semu dengan desain penelitian nonequivalent control group design. Populasi terdiri dari siswa kelas X MIPA dengan X MIPA 1 sebagai kelas eksperimen dan $X$ MIPA 4 sebagai kelas kontrol. Teknik pengambilan sampel dilakukan secara purposive sampling sehingga kelas sampel ditentukan oleh guru. Instrumen yang digunakan dalam penelitian berupa tes dalam bentuk pilihan ganda terdiri dari 20 butir soal dan 5 pilihan jawaban yang valid, reliabel dan daya pembeda soal serta indeks kesukaran dengan kriteria baik. Tingkat efektivitas e-modul dianalisis dari hasil uji $n$-gain. Hasil ngain yang diperoleh pada kelas eksperimen 0,6 sedangkan pada kelas kontrol 0,5 namun keduanya dalam kategori sedang. Sehingga e-modul larutan elektrolit dan nonelektrolit berbasis guided discovery learning efektif terhadap hasil belajar dengan kriteria tinggi dan efektif digunakan untuk meningkatkan hasil belajar peserta didik. Implikasi penelitian ini dapat dimanfaatkan untuk mendapatkan pengalaman langsung bagi siswa.
\end{abstract}

\begin{abstract}
A B S T R A C T
Electrolyte and nonelectrolyte solution material is one of the chemical material that is abstract and difficult for students to understandThe purpose of this study was to analyze the effectiveness of the emodule electrolyte and nonelectrolyte solution based on guided discovery learning on student learning outcomes. This type of research used quasi-experimental research design with nonequivalent control group design. The population consisted of students of class X MIPA at SMAN 7 Padang in the academic year 2020/2021 with X MIPA 1 as the experimental class and X MIPA 4 as the control class. The sampling technique was carried out by purposive sampling so that the sample class was determined by the teacher. The instrument used in the study was a test in the form of multiple choice consisting of 20 questions and 5 answer choices that were valid, reliable and discriminatory about the questions as well as a difficulty index with good criteria. The level of effectiveness of the e-module was analyzed from the results of the $n$-gain test. The $n$-gain results obtained in the experimental class are 0.6 while in the control class are 0.5 but both are in the medium category. So that the e-module electrolyte and nonelectrolyte solution based on guided discovery learning is effective on learning outcomes with high criteria and is effectively used to improve student learning outcomes.
\end{abstract}

\section{PENDAHULUAN}

Kimia merupakan ilmu yang sering dikaitkan dengan sifat-sifat esensial zat. Kimia membahas sistem yang cukup kompleks, mulai dari atom, molekul, serta senyawanya (Andani \& Yulian, 2018; Mujakir \& Rusydi, 2019). Oleh karena itu, pengajaran ilmu kimia dimulai dari konsep-konsep yang sederhana, kemudian dari konsep yang sederhana tersebut dibangun konsep-konsep yang lebih kompleks (Cheung, 2011; Pandaleke et al., 2020). Pemahaman konsep dengan benar merupakan landasan dalam memahami fakta, hukum, prinsip dan teori dalam ilmu kimia (Asmarisa et al., 2017). Pembelajaran kimia meliputi aspek yang dapat dilihat dengan indra yang berupa fakta konkret dan aspek tidak dapat dilihat 
dengan indra yang hanya bisa dipahami dengan logika. Dalam menginterpretasi dan memahami ilmu kimia membutuhkan keterkaitan tiga bentuk representasi yaitu makroskopik (nyata, dapat dilihat, disentuh dan dicium), submikroskopik (atom, molekul, ion dan struktur) dan representasional/simbolik (simbol, rumus, persamaan, molaritas, manipulasi matematis, dan grafik)(Eilks \& G.Zuin, 2018; Suardana \& Juniartina, 2020). Namun kenyataannya, dalam pembelajaran banyak peserta didik mengalami kesulitan dalam merepresentasikan aspek tersebut pemahaman siswa terkait materi kimia masih kurang (Nazalin \& Muhtadi, 2016; Suardana \& Juniartina, 2020). Hal inilah yang membuat peserta didik mengalami kesalahan konsep sebagai akibat dari kurangnya pemahaman konsep tentang aspek makroskopis yang berbeda dengan submikroskopis dalam pembelajaran kimia. Khususnya materi larutan elektrolit dan nonelektrolit merupakan salah satu materi pelajaran kimia yang bersifat abstrak sehingga menyebabkan kesulitan peserta didik dalam memahami materi larutan elektrolit dan nonelektrolit (Aisyah et al., 2021; Habibati et al., 2019). Sebagai contohnya kita dapat mengenali gejala-gejala yang terjadi pada interaksi ion tetapi tidak dapat mengamati secara langsung. Konsep ini akan mudah dipahami jika peserta didik diberikan ilustrasi berupa gambar atau animasi yang berhubungan dengan konsep materi larutan elektrolit dan nonelektrolit. Berdasarkan hasil angket yang telah diberikan kepada 3 guru kimia dan 97 orang siswa di SMAN 7 Padang diperoleh bahwa 60,8\% siswa mengalami kesulitan dalam pembelajaran kimia pada materi larutan elektrolit dan nonelektrolit.

Salah satu solusi untuk meningkatkan pemahaman siswa pada materi larutan elektrolit dan nonelektrolit dengam pemilihan model pembelajaran. Guided discovery learning salah satu model pembelajaran dimana siswa dapat mengapresiasikan dirinya dengan bebas dalam menyelidiki suatu konsep untuk pemahaman materi, dimana guru memberikan contoh kepada siswa terkait topik materi secara spesifik dan memandu siswa dalam memahami topic (Pramunando \& Yerimadesi, 2019; Sunismi, 2015). Guided discovery, guru merencanakan suatu rangkaian pernyataan atau pertanyaan yang membimbing siswa, langkah demi langkah secara logis, membuat serangkaian penemuan yang mengarah ke tujuan yang telah ditentukan. Dengan kata lain guru memulai stimulus dan siswa bereaksi dengan terlibat dalam penyelidikan secara aktif sehingga menemukan respon yang tepat (Sholeha, 2019; Sunismi, 2015). Dalam pelaksanaan guided discovery learning, peserta didik diarahkan dan dibimbing oleh guru untuk menemukan konsep secara mandiri, sehingga pengetahuan yang dimiliki peserta didik adalah hasil penemuannya sendiri (Destrini et al., 2018; Parno, 2015; Ulfa et al., 2017).

Guided discovey learning dapat melatih dan meningkatkan beberapa kemampuan peserta didik khususnya pada jenjang Sekolah Menengah Atas (SMA). Pada jenjang SMA, kemampuan yang dapat ditingkatkan seperti kemampuan memecahkan masalah serta kemampuan berpikir kritis. Pada model pembelajaran guided discovery learning untuk dapat memahami suatu konsep materi dibutuhkan bahan ajar sebagai sumber untuk melaksanakan proses pembelajaran. Bahan ajar seperti modul menuntut agar peserta didik aktif dan mandiri dalam proses pembelajaran. Modul efektif digunakan untuk meningkatkan hasil belajar peserta didik pada pembelajaran kimia, seperti pada materi larutan penyangga, kesetimbangan kimia dan ikatan kimia (Herawati \& Muhtadi, 2018; Pramunando \& Yerimadesi, 2019)(Wulandari \& Suparno, 2020). Dengan demikian, modul sangat membantu dalam proses pembelajaran. Beberapa temuan penelitian sebelumnya mengenai penggunaan modul berbasi GDL dapat meningkatkan motivasi belajar peserta didik serta memfasilitasi siswa dalam memahami materi yang bersifat abstrak sehingga memudahkan siswa memahami materi yang dapat meningkatkan hasil belajar siswa (Bayharti et al., 2019). Penelitian lain juga mengungkapkan pembelajaran menggunakan modul guided discovery learning dapat meningkatkan motivasi belajar dan hasil belajar peserta didik dalam proses pembelajaran (Yerimadesi et al., 2019). E-modul memiliki efek potensial yang terhadap hasil belajar sehingga dapat dikatakan bahwa penggunaan e-modul dalam proses pembelajaran meningkatkan hasil belajar siswa (Pramunando \& Yerimadesi, 2019). Penelitian ini memiliki perbedaan dengan penelitian sebelumnya pada materi yang digunakan yaitu materi larutan elektrolit dan nonelektrolit. Materi yang digunakan sesuai dengan tuntutan kurikulum saat ini. E-modul ini memiliki kategori kevalidasi dan praktiktisan yang tinggi. Pengembangan e-modul larutan elektrolit dan nonelektrolit yang dikembangkan sampai tahap penilaian (assement phase), dianalisis uji validitas dan praktikalitas, namun belum dilakukan uji efektivitas. Uji efektivitas e-modul belum dilakukan terhadap hasil belajar siswa sehingga e-modul belum bisa disebarkan lebih luas. Maka penelitian ini bertujuan untuk menganalisis efektivitas e-modul larutan elektrolit dan nonelektrolit berbasis GDL terhadap hasil belajar siswa kelas X MIPA di SMAN 7 Padang.

\section{METODE}


Jenis penelitian yang digunakan merupakan penelitian eksperimen semu (quasi experiment research) dengan desain nonequivalent control group design. Penelitian ini dilaksanakan pada semester genap tahun ajaran 2020/2021 di SMAN 7 Padang. Populasi penelitian terdiri dari peserta didik kelas X MIPA SMAN 7 Padang tahun ajaran 2020/2021 dengan kelas sampel yang digunakan yaitu X MIPA 1 (eksperimen) dan X MIPA 4 (kontrol). Teknik pengambilan sampel menggunakan purposive sampling sehingga kelas sampel ditentukan berdasarkan pertimbangan yang dilakukan oleh guru. Pembelajaran kelas ekperimen menggunakan e-modul larutan elektrolit dan nonelektrolit berbasis GDL sedangkan pada kelas kontrol menggunakan bahan ajar yang disediakan di sekolah. Intrumen penelitian yang digunakan yaitu berupa tes objektif terdiri dari 20 butir soal 5 pilihan jawaban dengan kriteria soal baik pada uji validitas, reabilitas, daya pembeda soal dan indeks kesukaran soal. Kelas sampel diberikan pretest sebelum melakukan pembelajaran dan posttest setelah pembelajaran berlangsung. Selanjutnya data yang telah didapatkan dilakukan uji n-gain sampai uji hipotesis.

\section{HASIL DAN PEMBAHASAN}

Hasil

Hasil penelitian diperoleh dari pretest dan posttest sebagai hasil belajar pada ranah kognitif. Pretest dilakukan sebelum pembelajaran dimulai sedangkan posttest dilakukan setelah dilakukan pembelajaran. Untuk menganalisis hasil belajar kelas sampel, maka dilakukan uji n-gain. Uji n-gain dilakukan untuk mengetahui tingkat keefektifan dari e-modul larutan elektrolit dan nonelektrolit berbasis GDL. Uji n-gain dianalisis berdasarkan hasil pretest dan posttest yang telah dilakukan. Hasil uji n-gain kedua kelas sampel yang diperoleh ditampilkan pada Tabel 1. menunjukkan adanya peningkatan hasil belajar dari kelas sampel sesudah dilakukannya proses pembelajaran. Rata-rata n-gain kelas eskperimen sebesar 0,6 sedangkan pada kelas kontrol 0,5. Rata-rata kedua kelas sampel dalam kategori sedang hanya selisih nilai 0,1. Hal ini menunjukkan bahwa e-modul larutan elektrolit dan nonelektrolit berbasis GDL lebih efektif meningkatkan hasil belajar siswa. Untuk membuktikkan bahwa e-modul efektif digunakan maka dilakukan uji statistik (uji hipotesis). Uji statistik yang dilakukan berupa uji normalitas, homogenitas dan uji hipotesis. Hasil uji normalitas dapat dilihat pada Tabel 2.

Tabel 1. Hasil n-gain Kelas sampel

\begin{tabular}{lccccc}
\hline \multicolumn{1}{c}{ Kelas } & N & Pretest & Posttest & Rata-rata n-gain & Kategori \\
\hline Eksperimen & 38 & 52,76 & 80,53 & 0,6 & Sedang \\
Kontrol & 36 & 52,64 & 77,36 & 0,5 & Sedang \\
\hline
\end{tabular}

Tabel 2. Hasil Uji Normalitas Kelas Sampel

\begin{tabular}{lllll}
\hline Kelas & $\mathbf{A}$ & $\mathbf{L}$ & Ltabel & Keterangan \\
\hline Eksperimen & & 0,143 & 0,144 & \\
Kontrol & 0,05 & 0,146 & 0,148 & Terdistribusi Normal
\end{tabular}

Berdasarkan pada Tabel 2 perolehan uji normalitas terlihat bahwa Lo yang didapatkan pada kedua kelas sampel < Lt. Sehingga dapat ditarik kesimpulan bahwa kedua kelas sampel terdistribusi normal dengan menggunakan ketetntuan besar taraf $\alpha 0,05$. Uji homogenitas dilakukan supaya tidak terdapat perbedaan atau ketidakhomogenan sampel (Radyuli dkk, 2019). Perolehan uji homogenitas dapat dilihat pada Tabel 3. Hasil analisis menampilkan $F_{h i t u n g}(1,73)<F_{\text {tabel }}(1,76)$ sehingga dapat ditarik kesimpulan bahwa kedua kelas sampel terdistribusi homogen dengan ketentuan besar taraf $\alpha 0,05$. Berdasarkan hasil uji normalitas dan homogenitas yang didapatkan bahwa terdistribusi normal dan varian homogen maka untuk uji hipotesis dilakukan uji kesamaan dua rata-rata. Perolehan uji hipotesis dapat dilihat pada Tabel 4. Hasil uji hipotesis didapatkan bahwa hasil thitung $(2,875)>\operatorname{ttabel}(1,67)$ yang menujukkan bahwa hipotesis penelitian diterima karena kelas sampel mempunyai perbedaan peningkatan hasil belajar yang signifikan. Dengan kata lain, penggunaan e-modul larutan elektrolit dan nonelektrolit berbasis GDL efektif terhadap hasil belajar peserta didik.

Tabel 3. Hasil Uji Homogenitas Kelas Sampel

\begin{tabular}{llll}
\hline Kelas & Fhitung $_{2}$ & $\mathbf{F}_{\text {tabel }}$ & Keterangan \\
\hline
\end{tabular}




\begin{tabular}{lccc}
\hline $\begin{array}{l}\text { Kelas kontrol dan } \\
\text { Eksperimen }\end{array}$ & 1,734536 & 1,76 & Homogen \\
\hline
\end{tabular}

Tabel 4. Hasil Uji Hipotesis Terhadap Kelas Sampel

\begin{tabular}{|c|c|c|c|c|c|c|}
\hline Kelas & $\mathbf{N}$ & $\mathbf{X}$ & $S_{\text {gab }}$ & $\mathbf{T}_{\text {hitung }}$ & $\mathbf{T}_{\text {tabel }}$ & Keputusan \\
\hline Eksperimen & 38 & 30,13 & 784 & 2875 & 167 & $\mathrm{H}_{0}$ \\
\hline Kontrol & 36 & 24,72 & 1,84 & $2,8 / 5$ & 1,07 & Ho ditolak \\
\hline
\end{tabular}

\section{Pembahasan}

Berdasarkan analisis data yang diperoleh dari kedua kelas sampel memiliki kemampuan awal yang hampir sama. Untuk menganalisis pengetahuan awal yang dimiliki peserta didik maka di awal pembelajaran diberikan pretest. Pengetahuan awal dari peserta didik berguna untuk membantu guru memperkirakan bagian materi mana yan akan diajarkan lebih mendalam, sehingga waktu yang digunakan saat pembelajaran lebih efektif. Pada akhir pembelajaran kedua kelas sampel diberikan posttest untuk menganalisis kemampuan peserta didik pada ranah kognitif. Pentingnya pengetahuan awal yang telah dimiliki oleh peserta didik dapat membantu guru memperkirakan bagian materi mana yang harus diajarkan lebih mendalam, sehingga waktu yang digunakan saat pembelajaran akan lebih efektif (Gazali \& Yusmaita, 2018). Oleh karena itu pentingnya pengguna media berupa e-modul dalam proses pembelajaran. E-modul efektif digunakan pada proses pembelajaran, hal ini dapat dilihat dari hasil belajar siswa dalam menggunakan e-modul. Menggunakan e-modul larutan elektrolit dan nonelektolit berbasis GDL menyebabkan hasil belajar peserta didik pada kelas eksperimen lebih tinggi dibandingkan dengan kelas kontrol dan secara signifikan membuktikkan bahwa e-modul efektif digunakan terhadap hasil belajar siswa. E-modul larutan elektrolit dan nonelektrolit berbasis GDL dapat dijadikan sebagai salah satu bahan ajar yang sangat mendukung proses pembelajaran. Penerapan model GDL memberi kesempatan kepada siswa untuk terlibat aktif dan memebrikan tanggung jawab kepada setiap siswa (Harianti, 2018; Kariman et al., 2019; Parno, 2015). Penggunaan e-modul berbasis GDL memudahkan peserta didik menemukan konsep materi dikarenakan peserta didik difasilitasi dengan bimbingan emodul berdasarkan sintak pada GDL dan efektif dalam menemukan pemahaman suatu konsep. Selain itu, penerapan GDL juga efektif dalam meningkatkan kemampuan berfikir kritis peserta didik (Sunismi, 2015; Yerimadesi et al., 2019). Selain itu, dengan model GDL siswa belajar secara mandiri baik didalam maupun diluar kelas (Romayanti et al., 2020). Hal ini sejalan dengan teori belajar konstruktivisme yang mengatakan bahwa pembelajaran dapat berjalan dengan efektif apabila peserta didik dapat membangun dan membentuk konsep sendiri yang telah dipelajari (Rahmatia et al., 2021). Sehingga e-modul berbasis GDL efektif digunakan pada proses pembelajaran, khususnya pada materi larutan elektrolit dan nonelektrolit.

Penggunaan e-modul larutan elektrolit dan nonelektrolit berbasis GDL merupakan salah satu faktor untuk meningkatkan hasil belajar dan pemahaman peserta didik. Penelitian lain juga mengungkapkan bahwa proses pembelajaran menggunakan e-modul berbasis GDL dapat meningkatkan motivasi beajar dan hasil belajar peserta didik. Temuan ini diperkuat dengan temuan penelitian sebelumnya menyatakan penggunaan modul berbasi GDL dapat meningkatkan motivasi belajar peserta didik serta memfasilitasi siswa dalam memahami materi yang bersifat abstrak sehingga memudahkan siswa memahami materi yang dapat meningkatkan hasil belajar siswa (Bayharti et al., 2019). Pembelajaran menggunakan modul guided discovery learning dapat meningkatkan motivasi belajar dan hasil belajar peserta didik dalam proses pembelajaran (Yerimadesi et al., 2019). E-modul memiliki efek potensial yang terhadap hasil belajar sehingga dapat dikatakan bahwa penggunaan e-modul dalam proses pembelajaran meningkatkan hasil belajar siswa (Pramunando \& Yerimadesi, 2019). Modul berbasis GDL efektif karena dengan modul ini dapat menjadikan pembelajaran menjadi tidak membosankan dan menyenangkan sehingga minat dan motivasi belajar siswa juga meningkat. Temuan ini diperkuat dengan temuan sebelumnya yang menyatakan penerapan media pembelajaran berupa e-modul dapat meningkatkan hasil belajar (Hafsah et al., 2016). Penggunaan e-modul meningkatkan kemandirian belajar pada kategori tinggi dan hasil belajar siswa pada kategori sedang (Linda et al., 2021). E-modul dapat meningkatkan motivasi belajar dan ketuntasan belajar peserta didik(Zaharah \& Susilowati, 2020). Dengan pemanfaatan e-modul larutan elektrolit dan nonelektrolit berbasis GDL secara maksimal, maka diharapkan hasil belajar siswa akan meningkat lebih optimal, hasil penelitian ini dapat digunakan sebagai salah satu alternatif model pembelajaran untuk menciptakan pemahaman yang lebih cepat terhadap 
proses pembelajaran dan menggunakan e-modul sebagai salah satu media pembelajaran yang dapat membangkitkan minat belajar siswa dan membuat pembelajaran lebih efektif lagi, Guru-guru dapat mengembangkan kreativitas dan lebih mengaktifkan siswa dalam proses belajar mengajar melalui modelmodel pembelajaran yang inovatif. Selain itu pihak sekolah juga harus menambah sarana dan prasarana penunjang proses pembelajaran agar proses pembelajaran nantinya lebih efektif dan mampu menambah daya tarik siswa dalam memahami materi pembelajaran. Implikasi penelitian ini dapat dimanfaatkan untuk mendapatkan pengalaman langsung dan dapat dijadikan informasi bagi para peneliti bidang pendidikan untuk meneliti aspek atau variabel dan dijadikan sebagai referensi untuk melakukan penelitian sejenis sebagai pedoman untuk melakukan penelitian pengembangan yang lebih menarik dan inovasi.

\section{SIMPULAN DAN SARAN}

Penggunaan e-modul larutan elektrolit dan nonelektrolit berbasis guided discovery learning terhadap hasil belajar efektif digunakan dalam proses pembelajaran. Penggunaan modul ini dinyatakan efektif yang ditunjukkan dengan peningkatan hasil belajar siswa.

\section{DAFTAR RUJUKAN}

Aisyah, R. S. S., Solfarina, S., \& Yuliantika, U. (2021). Pengembangan E-Modul Berbasis Pemecahan Masalah Pada Materi Larutan Elektrolit dan Non-Elektrolit (ELNOEL). Hydrogen: Jurnal Kependidikan Kimia, 9(1), 19-29. https://doi.org/10.33394/hjkk.v9i1.3715.

Andani, D. T., \& Yulian, M. (2018). Pengembangan Bahan Ajar Electronic Book Menggunakan Software Kvisoft Flipbook Pada Materi Hukum Dasar Kimia di SMA Negeri 1 Panton Reu Aceh Barat. Jurnal IPA Dan Pembelajaran IPA, 2(1), 1 - 6. https://doi.org/10.24815/jipi.v2i1.10730.

Asmarisa, N., Budiasih, E., \& Suharti. (2017). Efektivitas Pembelajaran LC 5E untuk Mengurangi Kesalahan Konsep Materi Redoks dan Retensinya pada SiswaK elas X. Jurnal Pendidikan: Teori, Penelitian Dan Pengembangan, 2(9), 1277-1282. https://doi.org/10.17977/jptpp.v2i9.10007.

Bayharti, B., Azumar, O. R., Andromeda, A., \& Yerimadesi, Y. (2019). Effectiveness of redox and electrochemical cell module based guided discovery learning on critical thinking skills and student learning outcomes of high school. , 1317(1), 0-5. Journal of Physics: Conference Series, 1317(1), 1-5. https://doi.org/10.1088/1742-6596/1317/1/012144.

Cheung, D. (2011). Evaluating Student Attitudes toward Chemistry Lessons to Enhance Teaching in the Secondary School. Educación Química, 22(2), 117-122. https://doi.org/10.1016/S0187893X(18)30123-X.

Destrini, H., Nirwana, \& Sakti, I. (2018). Penerapan Model Pembelajaran Penemuan Terbimbing (Guided Discovery Learning) untuk Meningkatkan Hasil Belajar dan Keterampilan Proses Sains Siswa. Jurnal Kumparan Fisika, 1(1), 13-21. https://doi.org/10.33369/jkf.1.1.13-21.

Eilks, I., \& G.Zuin, V. (2018). Editorial Overview: Green and Sustainable Chemistry Education (GSCE): Lessons to be learnt for a safer, healthier and fairer world today and tomorrow. Current Opinion in Green and Sustainable Chemistry, 13. https://doi.org/10.1016/j.cogsc.2018.08.007.

Gazali, F., \& Yusmaita, E. (2018). Analisis Prior Knowledge Konsep Asam Basa Siswa Kelas XI SMA untuk Merancang Modul Kimia Berbasis REACT. Jurnal Eksakta Pendidikan (Jep), 2(2), 202-208. https://doi.org/10.24036/jep/vol2-iss2/249.

Habibati, H., Nazar, M., \& Septiani, P. D. (2019). Pengembangan Handout Berbasis Literasi Sains Pada Materi Larutan Elektrolit dan Nonelektrolit. JIPI (Jurnal IPA \& Pembelajaran IPA), 3(1), 36-41.

Hafsah, RJ, N., Rohendi, D., \& Purnawan. (2016). Penerapan Media Pembelajaran Modul Elektronik Untuk Meningkatkan Hasil Belajar Siswa Pada Mata Pelajaran Teknologi Mekanik. Journal of Mechanical Engineering Education, 3(1), 106. https://doi.org/10.17509/jmee.v3i1.3200.

Harianti, F. (2018). Pengaruh Model Pembelajaran Guided Discovery Learning terhadap Kemampuan Pemahaman dan Hasil Belajar Siswa Materi Operasi Aljabar Kelas VII SMP. MUST: Journal of Mathematics Education, Science and Technology, 3(1), 82 - 91. https://doi.org/10.30651/must.v3i1.1611.

Herawati, N. S., \& Muhtadi, A. (2018). Pengembangan Modul Elektronik (E-Modul) Interaktif Pada Mata Pelajaran Kimia kelas XI SMA. Jurnal Inovasi Teknologi Pendidikan, 5(2), 180-191. https://doi.org/10.21831/jitp.v5i2.15424.

Kariman, D., Harisman, Y., Sovia, A., \& Prahmana, R. C. I. (2019). Effectiveness Of Guided Discovery-Based Module: A Case Study In Padang City, Indonesia. Journal on Mathematics Education, 10(2), 239 250. https://doi.org/10.22342/jme.10.2.6610.239-250. 
Linda, R., Zulfarina, M., \& Putra, T. P. (2021). Peningkatan Kemandirian Dan Hasil Belajar Peserta Didik Melalui Implementasi E-Modul Interaktif IPA Terpadu Tipe Connected Pada Materi Energi SMP/MTs. Jurnal Pendidikan Sains Indonesia, 9(2), 191-200. https://doi.org/10.24815/jpsi.v9i2.19012.

Mujakir, \& Rusydi. (2019). Pembelajaran Kimia Inovatif untuk Melatih Siswa Menjelaskan Masalah. Jurnal Ilmiah Didaktika: Media Ilmiah Pendidikan Dan Pengajaran, 20(1), $38 \quad$ - 57. https://doi.org/10.22373/jid.v20i1.4450.

Nazalin, N., \& Muhtadi, A. (2016). Pengembangan Multimedia Interaktif Pembelajaran Kimia Pada Materi Hidrokarbon Untuk Siswa Kelas Xi SMA. Jurnal Inovasi Teknologi Pendidikan, 3(2), 221. https://doi.org/10.21831/jitp.v3i2.7359.

Pandaleke, M., Munzil, \& Sumari. (2020). Pengembangan Media Pelajaran Kelas Flipped Berbasis Animasi untuk Meningkatkan Pemahaman Konsep Kimia. Jurnal Pendidikan: Teori, Penelitian Dan Pengembangan, 5(3), 387-394. https://doi.org/10.17977/jptpp.v5i3.13293.

Parno. (2015). Effect of Guided Discovery learning model in mastering of Force and Motion subject. Indosesian Journal of Applied Physics, 5(2), 1-9. https://doi.org/10.13057/ijap.v5i02.276.

Pramunando, W., \& Yerimadesi, Y. (2019). Pengembangan Modul Ikatan Kimia Berbasis Guided Discovery Learning untuk Kelas X SMA. Edukimia, 1(1), 9-15. https://doi.org/10.24036/ekj.v1.i1.a1.

Rahmatia, R., Pajarianto, H., Kadir, A., Ulpi, W., \& Yusuf, M. (2021). Pengembangan Model Bermain Konstruktif dengan Media Balok untuk Meningkatkan Visual-Spasial Anak. Jurnal Obsesi : Jurnal Pendidikan Anak Usia Dini, 6(1), 47-57. https://doi.org/10.31004/obsesi.v6i1.1185.

Romayanti, C., Sundaryono, A., \& Handayani, D. (2020). Pengembangan E-modul kimia Berbasis Kemampuan Berpikir Kreatif Dengan Menggunakan KVISOFT FLIPBOOK MAKER. Alotrop, 4(1). https://doi.org/10.33369/atp.v4i1.13709.

Sholeha, V. (2019). Efektivitas metode guided discovery pada pembelajaran sains terhadap perkembangan kognitif anak usia 5-6 tahun. Jurnal Pendidikan Anak, 8(1), 78-83. https://doi.org/10.21831/jpa.v8i1.26680.

Suardana, I. N., \& Juniartina, P. P. (2020). Analisis Kebutuhan Pengembangan Perangkat Pembelajaran Kimia Dasar Berbasis Inkuiri. Jurnal Pendidikan Matematika Dan IPA, 11(1), 62 - 73. https://doi.org/10.26418/jpmipa.v11i1.32556.

Sunismi. (2015). Developing Guided Discovery Learning Materials Using Mathematics Mobile Learning Application As An Alternative Media For The Students Calculus II. Cakrawala Pendidikan, 34(3), 334-346. https://doi.org/10.21831/cp.v3i3.7340.

Ulfa, K., Buchori, A., \& Murtianto, Y. H. (2017). Efektivitas Model Guided Discovery Learning untuk Video Pembelajaran dalam Mengetahui Perbedaan Kemampuan Pemecahan Masalah Matematika Siswa. MUST: Journal of Mathematics Education, Science and Technology, 2(2), 267-275. https://doi.org/10.30651/must.v2i2.888.

Wulandari, A., \& Suparno, S. (2020). Pengaruh Model Problem Based Learning terhadap Kemampuan Karakter Kerjasama Anak Usia Dini. Jurnal Obsesi : Jurnal Pendidikan Anak Usia Dini, 4(2), 862. https://doi.org/10.31004/obsesi.v4i2.448.

Yerimadesi, Y., Bayharti, B., Azizah, A., Lufri, L., Andromeda, A., \& Guspatni, G. (2019). Effectiveness of acidbase modules based on guided discovery learning for increasing critical thinking skills and learning outcomes of senior high school student. In Journal of Physics: Conference Series, 1185(1), 012151. https://doi.org/10.1088/1742-6596/1185/1/012151.

Zaharah, \& Susilowati, A. (2020). Meningkatkan Motivasi Belajar Peserta Didik Dengan Menggunakan Media Modul Elektronik Di Era Revolusi Industri 4.0. Biodik, 6(2), 39-52. https://doi.org/10.22437/bio.v6i2.8950. 